\title{
PALETA IZBIRE NA PODROČJU IZOBRAŽEVANJA ODRASLIH - RESNIČNOST IN OBETI
}

Izobraževanje odraslih naj bi se s sprejetjem načela vseživljenjskosti učenja in izobraževanja uveljavilo kot področje izobraževanja, ki je enakovredno izobraževanju $v$ otroštvu in mladosti. V praksi pa smo daleč od tega. Tudi zaradi tega, ker mnogi - med njimi vodilni politiki in tudi pedagoški strokovnjaki - na to enakovrednost gledajo s pridržki. Še vedno namreč menijo, da si otroci in mladostniki pri vzgoji in izobraževanju »zaslužijo« več pozornosti kot odrasli, saj so v obdobju, ko se še oblikujejo in razvijajo. To v praksi pomeni več sistemske podpore začetnemu izobraževanju - več finančnih sredstev, zakonsko urejenost, razvito infrastrukturo, zagotovljeno javno omrežje, skrb za izobraževanje učiteljev, sistem itn. Enakopravnosti in enakovrednosti začetnega in nadaljevalnega izobraževanja - tudi če bi se v celoti uresničila - ne gre razumeti kot enakosti obeh področij. Ali lahko ti dve področji, ki sta si v resnici zelo različni, sploh primerjamo? Cilji, namen, funkcije in tudi sam potek izobraževanja otrok in mladine so povsem drugačni kot pri izobraževanju odraslih. A to seveda ne pomeni, da je eno področje pomembnejše od drugega in da si zato zasluži več pozornosti javnosti, stroke in politike.

Izobraževanje odraslih označuje pestrost ciljev in pojavnih oblik, saj je namenjeno ljudem vseh starosti, ras, etnične pripadnosti, življenjskih stilov, kulturnih izkušenj; obsega cilje, povezane s področjem dela, zaposlitve, pa tudi osebnostnega razvoja in krepitve interesnih področij posameznikov. Ne nazadnje je tudi dejavnik socialnega, političnega in kulturnega
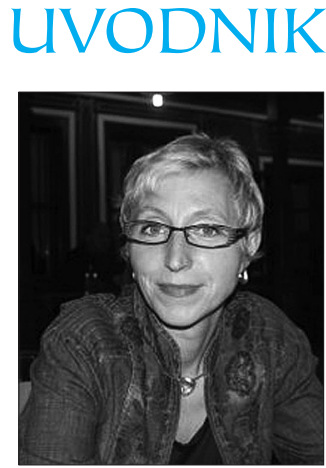

razvoja družbe, saj je tesno povezano z družbenimi gibanji (npr. za delavske pravice, mirovniškimi, ženskimi, civilnodružbenimi, kulturnimi, ekološkimi, prosvetiteljskimi idr. gibanji) $v$ preteklosti in danes, z razvojem civilne družbe in uravnavanjem socialne politike ter ima pomembno vlogo pri vzpostavljanju demokratične in konsenzualne komunikacije ter plodne javne sfere. Prav zaradi te pestrosti je področje izobraževanja odraslih lahko izredno vplivno pri zagotavljanju socialne pravičnosti (lokalno in globalno), saj izobraževalne dejavnosti neposredno nagovarjajo, popravljajo in odpravljajo različne družbene probleme, kot so brezposelnost, neenakost, rasizem, homofobija, nepismenost; posegajo na področje človekovih pravic, seksizma, revščine, izključenosti itn. Ena od pomembnih vlog izobraževanja odraslih je tako demokratizacija družbe in ozaveščanje ljudi o družbenih in političnih razmerah, $v$ katerih živijo.

Izobraževanje odraslih sledi tako individualnim kot družbenim ciljem. Njegova morda najpomembnejša funkcija je zmanjševanje razlik med generacijami in družbenimi skupinami glede izobraževalnih možnosti; pri tem je pomembna tako možnost doseganja enakih rezultatov kot tudi enake možnosti dostopa. Seveda je pomemben cilj izobraževanja odraslih tudi razvijati znanja in sposobnosti državljanov za dejavno udeležbo $v$ družbenem odločanju in sooblikovanju družbene realnosti. Ta cilj ima pogosto bodisi politični predznak in je zato po nepotrebnem podcenjen bodisi ga je zaradi drugačnih prioritet (zlasti ekonomskih) zelo 
težko uresničevati, vendar se stem njegov pomen ne zmanjšuje. $V$ zdajšnjih družbenih razmerah bi lahko rekli, da postaja vse pomembnejši in celo nujno potreben dejavnik razvoja demokratične in kritično refleksivne skupnosti (tako nacionalne kot globalne). Tretji ključni cilj izobraževanja odraslih, ki pa je danes politično najbolj favoriziran, je izobraževanje in usposabljanje za delo, poklic, zaposlitev. To področje je gotovo zelo pomembno, saj posamezniku omogoča strokovni razvoj in posledično tudi večjo kakovost življenja, pa vendar z dajanjem prednosti in večje pomembnosti enemu področju povzročamo neuravnoteženost pri razvoju celotnega področja izobraževanja. Enako pomemben cilj izobraževanja odraslih je nedvomno tudi zadovoljevanje posameznikove individualne potrebe po znanju, kar vključuje tako osebne interese kot tudi drugo možnost za zmanjševanje primanjkljajev, nastalih zlasti med začetnim izobraževanjem.

Da so ti cilji v Sloveniji po presoji strokovnjakov pomembni, dokazujejo tudi prednostna področja, opredeljena $v$ strokovnih podlagah za Nacionalni program izobraževanja odraslih, kjer se kot prvo prednostno področje postavlja splošno neformalno izobraževanje odraslih, kot drugo izobraževanje za zviševanje izobrazbene ravni prebivalstva, kot tretje pa izobraževanje in usposabljanje za razvoj delovne sile. Vendar pa analiza uresničevanja ReNPIO kaže, da je med strokovnimi zahtevami in politično voljo za uresničevanje zastavljenih ciljev precejšnje razhajanje, ki se zrcali med drugim v pomanjkanju sredstev za uresničitev nekaterih zastavljenih ciljev, v nezadostnem razvoju omrežja institucij, neustrezni podpori razvoju in izvedbi programov izobraževanja odraslih itn.

Večji del izobraževanja odraslih sestavlja neformalno izobraževanje, kar ni nenavadno, če vemo, da se odrasli za izobraževanje odločajo zaradi reševanja življenjskih problemov, doseganja konkretnih ciljev, zaradi druženja in vza- jemnega povezovanja ter solidarnosti, zato, ker si želijo boljšega sodelovanja med generacijami, zato, da bi pripomogli k razvoju skupnosti, kjer živijo, ali pa preprosto zato, da bi izboljšali kakovost svojega življenja. Le manjši delež odraslih (zlasti mlajši, ne pa izključno) se izobražuje zaradi zviševanja izobrazbene ravni. Kljub temu pa je potreba po formalnem izobraževanju odraslih v Sloveniji še kar velika, saj-kot ugotavljamo tudi $v$ analizah stanja za pripravo nove bele knjige - podatki kažejo, da nekaj več kot polovica prebivalstva, starejšega od 25 let, v letu 2008 ni imela končane štiriletne srednješolske izobrazbe, ki naj bi šele zagotavljala ustrezno udejstvovanje na različnih ravneh in področjih življenja v sodobni družbi. To je zelo skrb zbujajoč podatek, saj je tudi nadaljnja udeležba v izobraževanju tesno povezana $z$ začetno stopnjo izobrazbe posameznika in njegovo siceršnjo vpetostjo v družbene dejavnosti. Če pogledamo različne dostopne podatke o udeležbi odraslih v izobraževanju v Sloveniji, vidimo, da je to res, saj je udeležba v izobraževanju med različnimi skupinami zelo različna, v splošnem pa se-tako v formalno kot neformalno izobraževanje - najmanj vključujejo najmanj izobraženi, starejši odrasli in tisti, ki niso vključeni na trg delovne sile. In ne le to, Slovenija sodi med države z največjimi razlikami $v$ stopnji vključenosti med najmanj in najbolj izobraženimi, razlike pa so tako pri vključevanju $v$ formalno kot $v$ neformalno izobraževanje odraslih. Pri tem se potrjuje stališče, da je slaba udeležba nekaterih skupin prebivalstva v izobraževanju zlasti posledica izključevalnih družbenih praks (tudi izobraževanja), ki so tesno povezane z ideologijami moči, individualizma in kapitala. Prav ti podatki nas navajajo $k$ razmisleku, da bi se bilo treba v družbi, če si prizadeva za večjo pravičnost in socialno vključenost ranljivih skupin prebivalstva $v$ družbene dejavnosti (s čimer mislim tudi na zmanjševanje brezposelnosti, stigmatiziranosti, izključenosti iz procesov odločanja in podobno), z drugačnimi ukrepi in večjo senzibilnostjo lotiti reševanja teh problemov. 
Zahteve po pestrosti možnosti izobraževanja odraslih izhajajo tudi iz značilnosti odraslih, ki se učijo in izobražujejo. Odrasli se razlikujejo zaradi fizioloških, psiholoških in socioloških dejavnikov, pomembno pa vpliva tudi to, da odraslost zajema mnogo daljše obdobje kot otroštvo in mladost; zaradi tega so tako med starostnimi skupinami kot tudi znotraj posameznih starostnih skupin odraslih lahko zelo velike razlike. Huey B. Long v svojem prispev$k u$ »Understanding adult learners « navaja, da se razlike med ljudmi s starostjo povečujejo $v$ obliki črke V-starejši ko smo, bolj izrazite so. Odraslost torej ni generični pojem, saj se udeleženci izobraževanja odraslih med seboj razlikujejo po starosti, stopnji dosežene izobrazbe, poklicu, ki ga opravljajo (ali so ga opravljali), po vlogah, ki jih imajo, socialnem položaju, kulturnih, etničnih, rasnih, religioznih in drugih značilnostih, ki pomembno določajo položaj posameznika v procesu izobraževanja odraslih ter hkrati zahtevajo »neuniformirano « in netradicionalno izobraževalno ponudbo. Odrasli se seveda razlikujejo tudi po izkušnjah, motivaciji, odnosu do izobraževanja; razlikujejo se po sposobnostih, stilih spoznavanja in učnih stilih, po pristopih $k$ učenju ali pa po posebnih potrebah, ki izhajajo iz pridobljenih ali prirojenih lastnosti. $\mathrm{Na}$ pripravljenost za izobraževanje ne nazadnje vpliva tudi kraj, kjer posameznik živi, saj je ponudba izobraževanja veliko večja v urbanih središčih kot v ruralnem okolju, v Sloveniji pa so velike tudi razlike med regijami.

Iz različnosti potreb odraslih udeležencev izobraževanja izhajajo tudi potrebe po raznoliki ponudbi izobraževanja, saj se odrasli ne izobražujejo le v institucijah, ki so namenjene izobraževanju in usposabljanju, temveč tudi na mnogih drugih mestih, seveda pa se nekateri odrasli učijo tudi sami. Med odraslimi so torej glede učenja pomembne razlike, $k i$ - gledano splošno - izhajajo predvsem iz vprašanj, zakaj se učijo, kako njihovo učenje poteka, kdo jim pri tem pomaga (če jim sploh), katere vire uporabljajo pri učenju, koliko časa porabijo za učenje, kako načrtna je njihova dejavnost, ter drugih značilnosti, ki pomembno vplivajo na sam učni proces. $V$ grobem lahko izbirajo med programi formalnega in neformalnega splošnega in poklicnega izobraževanja odraslih, med katerimi so zlasti programi neformalnega izobraževanja odraslih zelo pestri. Če omenim le nekatere od njih: različni programi skupnostnega izobraževanja (študijski krožki, programi medgeneracijskega izobraževanja, izobraževanje za dejavno državljanskost itd.), programi za zviševanje ravni pismenosti (programi UŽU) za različne skupine odraslih, npr. za manj izobražene odrasle - Most do izobrazbe, za manj izobražene starše osnovnošolskih otrok - Beremo in pišemo skupaj, za manj izobraženo podeželsko prebivalstvo - Izzivi podeželja, za odrasle s posebnimi potrebami-Moj korak, za manj izobražene zaposlene osebe Moje delovno mesto, izobraževalni programi za starejše ljudi (npr. v okviru Slovenske univerze za tretje življenjsko obdobje, medgeneracijskih društev, društev upokojencev itd.), programi za mlajše odrasle, zlasti tiste osipnike, ki se v začetno izobraževanje ne zmorejo ali ne želijo vključiti (program PUM - Projektno učenje za mlade) itd. Odrasli se seveda izobražujejo tudi $v$ različnih (strokovnih in ljubiteljskih) društvih, knjižnicah, na univerzah, v skupnostnih središčih, inštitutih, $v$ delovnih organizacijah, prostovoljskih organizacijah, cerkvah, muzejih, bolnišnicah in zavodih, s čimer možnosti še zdaleč nismo izčrpali. Pri tem imajo na voljo tudi različne podporne dejavnosti, kot npr. različne oblike pomoči $v$ svetovalnih središčih (ISIO), možnost samostojnega učenja v Središčih za samostojno učenje, na voljo je Borza znanja in druge neformalne dejavnosti.

Kljub potrebam po raznoliki izobraževalni ponudbi za različne skupine odraslih pa lahko ugotovimo, da se izobraževanje odraslih tudi v Sloveniji vse bolj ravna po tržnih načelih in 
da država bolj financira programe, namenjene potrebam dela in zaposlitve, kar posledično vpliva na zmanjševanje izobraževalnih možnosti za ranljive skupine odraslih. Izvajanje nekaterih zgoraj omenjenih izobraževalnih programov je zaradi odvisnosti od vladnih sredstev lahko vsako leto ogroženo, kar zlasti javne organizacije za izobraževanje odraslih, ki povečini izvajajo neprofitne programe izobraževanja odraslih, postavlja v nezavidljiv položaj.

Povsem jasno je, da so v teh procesih pomembni dobri »učitelji« odraslih, mentorji, tutorji, svetovalci, skratka različni posamezniki, ki imajo tako spodbujevalno kot podporno vlogo, redko pa so v vlogi »tradicionalnega učitelja, ki prenaša znanje. V teh vlogah so lahko tako andragogi kot tudi drugi strokovnjaki, ki delujejo kot andragoški delavci; eni in drugi imajo zelo različne vloge, kar bogati proces dela z odraslimi. So učitelji, ki odrasle poučujejo (pri tem je pomemben enakopraven odnos med učiteljem in učečimi se, ki so dejavni, sodelujejo pri postavljanju ciljev, sooblikujejo učni proces itn.), so svetovalci odraslim in imajo podporno vlogo, lahko sodelujejo pri načrtovanju programov izobraževanja itn. Izredno pomembno je, da so učitelji odraslih in drugi andragoški delavci ustrezno izobraženi, teoretsko in praktično podprti, pripravljeni, da razmišljajo o načinu dela $z$ odraslimi, poznajo didaktična načela, izbirajo in uporabljajo ustrezne metode poučevanja, so vešči spodbujevalne komunikacije in tudi sami verjamejo, da kakovostno izobraževanje, prilagojeno različnim potrebam odraslih, lahko pripelje do sprememb. Kot pravi Daloz, je cilj izobraževanja odraslih spodbujati pripravljenost za učenje, katerega posledica je razvoj, ta pa pomeni sukcesivno postavljanje globljih in širših vprašanj o odnosu med posameznikom in svetom. To velja za vse starosti. Ravno zato je treba posebej poudariti, da je še zlasti pomembno tisto izobraževanje, ki pri odraslih spodbuja refleksijo, kritično mišljenje in presojanje družbenih razmer in možnosti, kar krepi pripravljenost za dejavno (so)delovanje $v$ družbenem prostoru; pomembno je torej izobraževanje, ki posledično krepi moč civilne družbe. V civilni družbi poteka privilegiran proces neinstrumentalnega učenja, učenja, ki povezuje kognitivni, emocionalni in socialni vidik ter tako razvija znanja in spretnosti, vpliva na čustva, stališča in motivacijo ter spodbuja interakcijo med posameznikom in okoljem. Zaradi tega je izobraževanje odraslih dejavnost, ki vpliva tako na poklicno kot tudi na osebno, skratka celovito življenjsko pot posameznika.

Žal pa se vse zgoraj napisano ne uresničuje tako, kot bi si želeli. Ključni so problemi, navedeni na začetku prispevka, povezani s sistemsko neurejenostjo področja izobraževanja odraslih (neustrezna zakonodaja, financiranje, neobstoj javne mreže in javnih programov, nezadostno razvita infrastruktura, neinstitucionaliziranost raziskovalne dejavnosti itn.) in njegovo marginaliziranostjo (neustrezna umeščenost izobraževanja odraslih $v$ sistem izobraževanja $v$ Sloveniji in neenakopravnost področja izobraževanja odraslih $v$ primerjavi z izobraževanjem otrok in mladine), kar se zrcali $v$ neustrezni podpori razvoju področja. Tudi andragogika kot akademska disciplina se ne razvija povsem tako, kot bi si želeli; delno je za to krivo pomanjkanje ustrezno usposobljenih raziskovalcev, ki bi lahko izvajali raziskave tako na nacionalni kot mednarodni ravni, delno pa je to tudi posledica neustrezne podpore ministrstev (navedimo za primer ravnanje slovenske šolske politike, ki ni zagotovila sredstev za vključitev Slovenije v evropsko raziskavo PIAAC, ki poteka v okviru OECD; gre za zbiranje podatkov o udeležbi odraslih $v$ izobraževanju ter znanju in veščinah odraslih prebivalcev evropskih držav, s čimer je ministrstvo za šolstvo in šport pretrgalo več kot desetletno spremljanje omenjenih podatkov $v$ Sloveniji in možnost, da poglobljeno primerjamo Slovenijo z Evropo). Marginaliziranost 
področja nadaljevalnega izobraževanja se kaže tudi v prepogosto neustrezno izobraženih učiteljih in drugih strokovnjakih, ki delajo na področju izobraževanja odraslih; to so nemalokrat učitelji, ki v dopoldanskem času poučujejo mladino, nimajo izkušenj z izobraževanjem odraslih in imajo tudi (pre)malo teoretskega znanja.

Javna politika na področju izobraževanja odraslih ta čas v Sloveniji (in tudi v marsikateri drugi evropski državi) ne uresničuje ideje, da je izobraževanje temeljna državljanska pravica. Med ukrepi za zagotavljanje dostopnosti izobraževanja je namreč ravno ustrezno financiranje izobraževanja (odraslih) tisti element, ki zagotavlja socialno pravičnost in vključenost vsega prebivalstva $v$ družbo. Če želimo ugotoviti, kakšna je vloga izobraževanja odraslih pri zmanjševanju marginalnosti ranljivih skupin, pa je treba prevrednotiti nasprotujoča si pojmovanja o vlogi izobraževanja odraslih $v$ odnosu do posameznika, družbe in različnih ekonomskih, socialnih, političnih in kulturnih vplivov. Izobraževanje odraslih je tesno povezano s politiko in ga moramo vedno presojati $v$ luči njegove družbene funkcije v nekem družbenem sistemu.

Kako torej enostavno odgovoriti na vprašanje, kakšna je danes vloga izobraževanja odraslih v Sloveniji in kako razvit je celoten sistem? Odgovoriti na to vprašanje je skoraj nemogoče, saj se resnična razvitost področja ne sklada vedno z naprednimi idejami, ki se porajajo v praksi izobraževanja odraslih in tudi $v$ teoretskih razpravah različnih strokovnjakov (in pogosto zaradi neustrezne podpore ne zmorejo zares zaživeti). Menim, da je bila Slovenija po osamosvojitvi zares neverjetna $v$ svojem razvoju zlasti na področju neformalnega izobraževanja odraslih, saj je bila - ob ustrezni politični podpori, ki je temeljila tudi na ustreznem razumevanju pomena izobraževanja v novi, razvijajoči se državi, upoštevajoč ljudi v vseh življenjskih obdobjih in ob zavedanju, kako pomembno je tako formalno kot neformalno izobraževanje odraslih - ena najbolj inovativnih, na znanju temelječih mladih državic. Verjetno tudi ni naključje, da se je ravno takrat politična kultura ob sorazmerno močni civilni družbi, kritičnih in ustvarjalnih državljanih tako hitro razvijala; skoraj smo lahko stopili ob bok $k$ stalnemu učenju naravnavi skandinavski druščini socialnih držav. V zadnjem času bi se s tem $v$ Sloveniji zares težko pohvalili.

Z gotovostjo pa lahko tudi danes trdimo, da sta širina in raznolikost področja izobraževanja odraslih njegova prednost in ne slabost. $Z$ zornega kota političnega urejanja teh vprašanj je to pogosto problem, po eni strani zaradi birokratizacije odločanja o načinih sistemskega urejanja in financiranja področja, česar gotovo ni mogoče enostavno urediti »po kopitu«izobraževanja otrok in mladine, po drugi strani pa tudi zaradi slabega poznavanja področja izobraževanja odraslih in nezainteresiranosti državnih uradnikov, ki mnogokrat brez posvetovanja s stroko odločajo o usodi različnih izobraževalnih dejavnosti za odrasle ali pa se jim ne zdi pomembno o tem odločati.

Čas je torej, da se zaposleni na področju izobraževanja odraslih in andragoška stroka ustrezno zavzamejo in organizirajo, da pospešijo ugodnejši razvoj že uveljavljenih praks ter znova spodbudijo razcvet področja izobraževanja odraslih, ki prej ali slej vpliva tudi na družbeno blaginjo.

Sabina Jelenc Krašovec

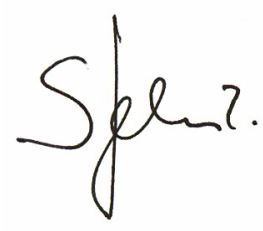

